\title{
A Tale of Two Isolates-Ainu Paradigm
}

\author{
Seun Ayoade* \\ Department of Physiology, Nigeria \\ *Corresponding author: Seun Ayoade, BSc (Hons) Independent Researcher, P.O. Box 22325, Nigeria
}

\section{Opinion}

"I hope, however, it will be a long time before any other supersedes the MUSICAL Yoruban tongue" [1] REV. R. H. STONE. 'Yoruba is a tonal language. The same combination of vowels and consonants has different meanings depending on the pitch of the vowels. For example, the same word -ARO can mean 'cymbal', 'indigo dye', 'lamentation' and 'granary' depending on intonation'. -Junior World mark Encyclopaedia of World Cultures. In linguistics there is a phenomenon called a "language isolate". This is when a group of people speak a language which is totally unrelated to the language or languages spoken by the peoples surrounding them. Usually people in each area speak related languages- often because they are of the same or similar genetic stock. [2] Yoruba is a language isolate [3]. It is totally unrelated to all other languages within Nigeria and in North, Central, Western, Eastern and Southern Africa.

Like Yoruba, the Ainu language spoken by The Ainu People of Northern Japan is a language isolate, and The Ainu are isolate speakers. They say two heads are better than one, and so many sources will be consulted in this extra linguistic proof that Yoruba indeed is a language isolate. In other words, this is a situational, socio-cultural, historical and scientific comparison of two language isolate speaker's vis a vis their neighbours. Let us explore the paradigm of the Ainu and Yoruba isolate speakers viz- "In the northern part of the Japanese archipelago are to be found the Ainu, or Aino. They number around 16,000 and $90 \%$ of their settlements are in Hokkaido. Practically all the remainder are in Sakhalin, which now belongs to the USSR. THEIR LANGUAGE IS ENTIRELY DISTINCTIVE [4]. "Although there have been attempts to show that the Ainu language and the Japanese language are related, modern scholars have rejected that the relationship goes beyond contact, such as the mutual borrowing of words between Japanese and Ainu. No attempt to show a relationship with Ainu to any other language has gained wide acceptance, and Ainu is currently considered to be a language isolate. Words used as prepositions in English (such as to, from, by, in and at) are postpositional in Ainu; they come after the word that they modify. A single sentence in Ainu can be made up of many added or agglutinated sounds or affixes that represent nouns or ideas.

The Ainu language has had no system of writing and has historically been transliterated by the Japanese kana or Russian Cyrillic. Today, it is typically written in either katakana or Latin alphabet. The unwieldy nature of the Japanese kana with its inability to accurately represent coda consonants has contributed to the degradation of the original Ainu. For example, some words, such as Kor (meaning "to hold"), are now pronounced with a paragoge, as in Koro. Many of the Ainu dialects, even from one end of Hokkaido to the other, were not mutually intelligible; however, the classic Ainu language of the Yukar, or Ainu epic stories, was understood by all. Without a writing system, the Ainu were masters of narration, with the Yukar and other forms of narration such as the Uepeker (Uwepeker) tales, being committed to memory and related at gatherings, often lasting many hours or even days" [5].

\section{Differences Between the Ainus and the Other Japanese}

\section{Location}

Ainu confined to northern Japanese island of Hokkaido (called Yezo in the past).

\section{Physical Appearance}

Ainu are physically bigger and taller than other Japanese. Ainu eyes often lack an epicanthus (slant) or have less prominent ones. Some Ainu also have beetled eyebrows. It is not unusual to see blue or green eyes among them. In comparison, mainstream, mainland (Yayoi) Japanese have brown eyes. In addition, blonde and red hair is not unheard of among the Ainu compared to the jet-black hair of the regular Japanese. Ainu also have longer nosed and hirsutism 
compared to their much more numerous neighbours. "The Ainu are somewhat taller than the Japanese, stoutly built, well proportioned, with dark-brown eyes, high cheek-bones" [6]. "Because they are very hirsute, they are popularly called "the hairy Ainu". THEY ARE CLASSIFIED AS WHITES and have been racially linked to some of the inhabitants of Siberia. In ancient times The Ainu were divided into several tribes, collectively known as The Emishi. They were fierce and warlike and were driven north by the Japanese only after a long struggle, but later tended to trade and intermarry with Japanese frontiersmen'. [7] "On the north-east coast of Yezo and in Shikotan (Kurile Islands) I saw some Ainu who, contrary to the rule, had red hair" [8].

'Ai'nos, a primitive thick-set, hairy race, now confined to Yezo and the islands N. of Japan, aboriginal to that quarter of the globe, and fast dying out.' [9] "The physical characteristics of the Aino-short stature, flattened humerus and tibia, heavy beards, and general hirsuteness (much exaggerated by travellers), lighter skin, dolichocephaly and brachycephaly, somewhat regular features, and non-savage looks-have given rise to theories of relationship with almost every known race. Drinton (1890) allies them with the Giliaks of the Amur; Deniker (1900) considers them sui generis; Keane (1896) and Baelz (1901) believe them to have been originally of the Caucasian (white) race. The last, who has studied the Aino at first hand, is of the opinion that they are the extreme eastern branch of a race related to the Caucasian stock, once occupying much of North-eastern Asia, but split into two sections by the inroads of the Mongol-Turkish peoples at a very remote date, a view which has a good deal to commend it. But the Aino are not a uniformly pure type, as the differences between those of Yezo and of Saghalien show. The linguistic, geographical, and mythological researches of B. H. Chamberlain (1887) and Bachelor (18821894) prove both the uniqueness of the Aino tongue and the great influence upon Japanese life exerted by that people in times past. Driven northward from their ancient habitat in south-western and central Japan, they have left their names on the natural features of the archipelago". [10]

'People have classified the Ainu as Mongolians, notwithstanding that they possess no characteristics whatsoever of the Mongolian races.

The colour of their skin is light reddish-brown, and not yellow and sallow, like that of Mongolians; they are very hairy, and the Mongolians are smooth-skinned; the features of the one race are diametrically opposed to those of the other; the mouth is strong and firm in the Ainu and weak in the Mongolian; and the Ainu eyes, the strongest characteristic of Mongolian races, do not slant upwards, nor are they long and almond-shaped, as with the Chinese or the Japanese, but with their long axes are in one horizontal plane, as in most Europeans. Indeed, the Ainu have a much greater resemblance to the Northmen of Europe in their prehistoric stage than to any modern races, and least of all to the Mongolians. But let us examine the eye more carefully. The iris is light brown, sometimes tending towards dark grey. One seldom sees black or very dark brown eyes save in half-breeds; and they are deeply set, as with Europeans' [11].

\section{Cultural}

Ainu almost always cook their meat and fish. No sushi etc. among them compared to regular Japanese. The Ainu practise animism rather than Shinto. 'They never eat raw fish or flesh, but always either boil or roast it' [12].

\section{Differences Between the Yorubas and the Other Nigerians and West Africans}

'Perhaps in no one area are we so favourably impressed with the Yoruba people as in the language, the vehicle of their ideas. IT HAS NO CLASSIFICATION WITH ANY OF THE AFRICAN TONGUES. The language is most difficult because of the innumerable contractions made by the natives in rapid speaking. Many words have several meanings which are determined only by the accent given them. For instance, OJO signifies 'coward', 'rain' or a man's name, either of which can only be known by the accent, so that if it be in the least changed, nonsense is the result and a stupid glare is the answer of the native. So difficult can the language be rendered by theses contractions and accents that the natives may be heard puzzling each other by their exercises while the singing of one town cannot be readily understood by the people of another. It is rather a smooth than a rough, and more a MUSICAL than an inharmonious language' [13].

\section{Location}

Yorubas found in south-western tip of Nigeria.

\section{Fertility}

Yoruba women more fertile than other Nigerian women. In fact, Yoruba women most, fertile women on earth! [14]

\section{Haemoglobin}

Yorubas suffer from abnormal haemoglobin $\mathrm{C}$ while other Nigerians/Africans suffer from abnormal haemoglobin S (Sickle Cell) $[15,16]$.

\section{Precolonial Urbanism}

'The Yoruba are unusual among Africans in their tendency to form urban communities' [17]. 'Noted for their long tradition of urban residence, the Yoruba' [18]. 'By (the year) 1400, The Yoruba were already organized in a complex system of city states' [19]. 'Perhaps the most remarkable thing about the Yoruba is their habit of living in towns. At all periods, even in the greatest days of Timbuktu, Djenne or Gao the largest towns in West Africa have been The Yoruba ones, unknown to the outside world' [20]. 


\section{Genetic Variations}

Peculiar variations observed in Yoruba genes include variations in genes controlling hair formation and patterning, metabolizing mannose, regulating dietary fatty acids, brain development and function/ neurotransmission and dystrophin binding [21].

\section{Conclusion}

Itis highly improbable that people sogenetically, physiologically and socio culturally different would speak a language of the same family as their neighbours. It rarely, if ever happens. Take for instance the Khoisan/Sandawe people of South Africa who speak the Sandawe click language isolate. Though black skinned, they have the "oriental" eyes [epicanthic fold/epicanthus]. The radical differences between The Ainu and the other Japanese and The Yoruba and the other Nigerians is proof positive and further confirmation that Yoruba is a language isolate.

\section{Greenberg's Great Gaffe}

Today, The Yoruba language, which is a language isolate [3] is often erroneously classed as being in the "Niger Congo" family. The man responsible for this flawed classification was an individual called JH Greenberg (died 2001). One of the worst things a researcher can do is to have a very strong bias towards a particular outcome BEFORE carrying out experimentation. This was the bane and Achilles heel of the work carried out by the partly self-styled linguist called Greenberg. Greenberg was hell bent on reducing ALL African languages to set 'families' and was not perceptive enough to realize that not every tongue on the continent would fit into his artificial straight jacket. After and even at the height of Greenberg's career, most of his contemporaries were doubtful of his conclusions and it is no doubt due to Greenberg's international connections that his flawed classification system came to prevail. Greenberg's work on African languages has been criticised by Lyle Campbell and Donald Ringe, who do not believe that his classification is justified by his data; they request a re-examination of his macrophyla by "reliable methods" (Ringe 1993:104). Harold Fleming and Lionel Bender, who are sympathetic to Greenberg's classification, acknowledge that at least some of his macrofamilies (particularly Nilo-Saharan and Khoisan) are not accepted completely by most linguists and may need to be divided (Campbell 1997). Their

(C) This work is licensed under Creative (c) Commons Attribution 4.0 License

To Submit Your Article Click Here: Submit Article

DOI: $10.32474 /$ PRJFGS.2019.03.000154 objection is methodological: if mass comparison is not a valid method, it cannot be expected to have brought order successfully out of the confusion of African languages [22,23].

\section{References}

1. R H STONE (2011) In Afric's Forest and Jungle OR Six Years Among the Yorubans, 1899 BY FLEMING H REVELL COMPANY 49(3): 280.

2. Chambers' Encyclopaedia (1970) International Learning Systems Corporation Ltd, London 8: 347.

3. Seun Ayoade (2018) Argument for The Reclassification of Yoruba as A Language Isolate. Peer Re J Foren \& Gen Sci 2(4).

4. Chambers' Encyclopaedia (1970) International Learning Systems Corporation Ltd, London 1: 175.

5. Shibatani, Masayoshi (1990) The Languages of Japan. Cambridge University Press pp. 3-5.

6. Encyclopaedia (1911) Britannica 1: 441-442.

7. Chambers' Encyclopaedia (1970) International Learning Systems Corporation Ltd, London 1: 175.

8. AHS Landor (2012) Alone with the hairy Ainu.

9. PA Nuttall (1907) The Nuttall Encyclopædia.

10. (1902) The New International Encyclopædia pp. 232-233

11. AHS Landor (2012) Alone with the hairy Ainu.

12. Encyclopaedia (1911) Britannica 1: 441-442.

13. William H Clark (1872) Travels and Explorations In Yorubaland (18541858) Ibadan University Press pp. 269-271.

14. (2008) Indian J Hum Genet 14(2): 41-47.

15. (2011) Indian J Physiol Pharmacol 55(4): 295-296.

16. Akinyanju OO (1989) A profile of sickle cell disease in Nigeria, Ann N Y Acad Sci 565: 126-136.

17. (1989) The Longman Encyclopeadia $1^{\text {st }}$ (Edn.), Colombia University press pp. 1167.

18. (1980) Macmillan Family Encyclopaedia pp. 331.

19. Cathal JN, Greenwood Encyclopaedia of International Relations 4: 1890.

20. History of West Africa 1000-1700AD pp. 72-73.

21. Voight BF, Kudaravalli S, Wen X, Pritchard JK (2006) A map of recent positive selection in the human genome. PLoS Biol 4(3): 72.

22. Greenberg, Joseph H (1963) The Languages of Africa. International journal of American linguistics 29 (1): part 2.

23. Greenberg, Joseph H (1966) The Languages of Africa 2nd (Edn.), Bloomington: Indiana University.

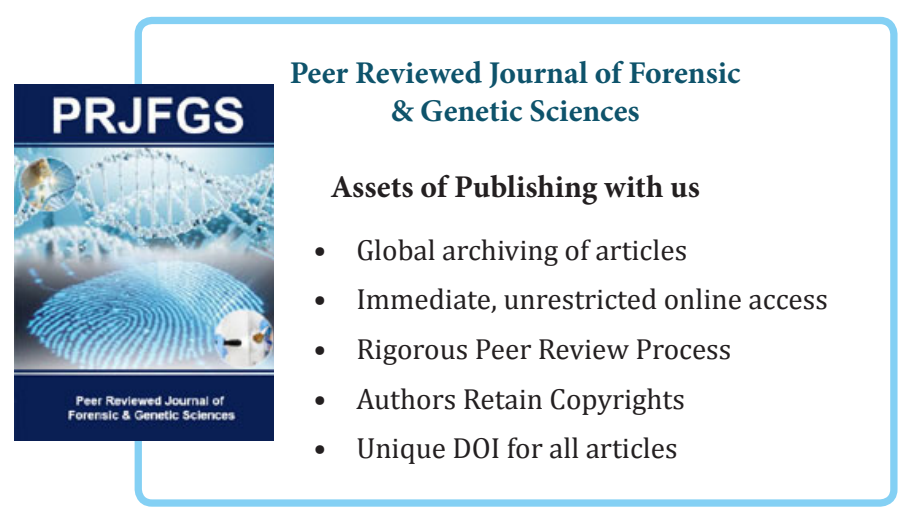

